\title{
EFFECT OF HIGH-INTENSITY EXERCISE ON ENDOTHELIAL FUNCTION IN PATIENTS WITH T2DM
}

\author{
EFEITO DO EXERCICIO DE ALTA INTENSIDADE NA FUNÇÃO ENDOTELIAL DE PACIENTES COM DM2
}

EFECTO DEL EJERCICIO DE ALTA INTENSIDAD SOBRE LA FUNCIÓN ENDOTELIAL DE PACIENTES CON DM2

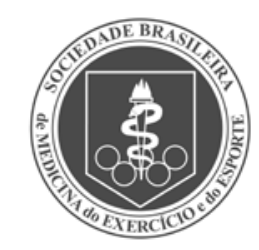

Original Article ARTIGo ORIGINAL Artículo Original
Carlos Alberto da Silva' (Educador Físico)

Francisco Sérgio Lopes Vasconcelos-Filho ${ }^{2}$ (Educador Físico) Marcus Serafim³ (Médico) Edson Botura ${ }^{4}$ (Médico) Roberta Cristina da Rocha-e-Silva ${ }^{2}$ (Médica Veterinária)

Christina Pacheco² (Bióloga)

Fernando Antônio Oliveira Marques (Educador Físico)

Sebastião Iberes Lopes Melo ${ }^{5}$ (Educador Físico)

1. Universidade Federal do Ceará, Instituto de Educação Física e Desportos, Fortaleza, CE, Brazil. 2. Universidade Estadual do Ceará, Instituto Superior de Ciências Biomédicas, Fortaleza, CE, Brazil.

3. Cardio Vita - Cardiologia e

Medicina do Esporte, Blumenau, SC, Brazil.

4. Clínica de Radiologia Uniangio, Blumenau, SC, Brazil.

5. Centro de Educação Física e Desportos, Universidade Estadual de Santa Catarina, Florianóplolis, SC, Brazil.

Correspondência: Av. Mister Hull, s/n, Parque Esportivo, Bloco 320, Campus do Pici, Fortaleza, CE, Brazil. 60455-760. carlosas@ufc.br

\begin{abstract}
Introduction: Diabetes mellitus is the most common metabolic disease worldwide. Endothelial dysfunction characteristic of these patients is one of the major risk factors for atherosclerosis. Early diagnosis of endothelial dysfunction is essential for the treatment especially of non-invasive manner, such as flow mediated dilation. Physical exercise is capable of generating beneficial adaptations may improve endothelial function. Objective: Identify the effect of physical exercise, using the clinical technique of ultrasound in the assessment of the endothelial function of patients with metabolic syndrome or type 2 diabetes mellitus. Methods: Thirty-one patients with type 2 diabetes mellitus or metabolic syndrome were studied, with a mean age $( \pm S D)$ of $58 \pm 6$ years, randomized into three groups. The training was performed for 50 minutes, four times a week. Before and after six weeks of training, subjects performed the endurance test and a study of the endothelial function of the brachial artery by high-resolution ultrasound. Results: After hyperemia, the percentage of arterial diameter was significantly higher for the high-intensity group $(\mathrm{HI}$ before $=2.52 \pm 2.85 \mathrm{~mm}$ and after $=31.81 \pm 12.21 \mathrm{~mm}$; L L before $=3.23 \pm 3.52 \mathrm{~mm}$ and after $=20.61 \pm 7.76 \mathrm{~mm}$; controls before $=3.56 \pm 2.33 \mathrm{~mm}$ and after $=2.43 \pm 2.14 \mathrm{~mm} ; p<0.05$ ). Conclusions: The high-intensity aerobic training improved the vasodilatation response-dependent endothelium, recorded by ultrasound, in patients with metabolic syndrome and type 2 diabetes.
\end{abstract}

Keywords: ultrasonics; diabetes mellitus; type 2; exercise.

\section{RESUMO}

Introdução: Diabetes melittus é a doença metabólica mais comum no mundo. A disfunção endotelial característica desses pacientes é um dos principais fatores de risco para aterosclerose. O diagnóstico precoce da disfunção endotelial é imprescindível para o tratamento, sobretudo, de maneira não invasiva, tal como dilatação mediada pelo fluxo. O exercício físico é capaz de gerar adaptações benéficas podendo melhorar a função endotelial. Objetivo: Identificar o efeito do exercício físico de alta intensidade, usando a técnica clínica de ultrassom, na avaliação da função endotelial de pacientes com síndrome metabólica ou diabetes mellitus tipo dois. Métodos: Foram estudados 31 pacientes com diabetes mellitus tipo dois ou síndrome metabólica, com média de idade ( \pm DP) de $58 \pm 6$ anos, distribuidos aleatoriamente em três grupos. O treinamento foi realizado por 50 minutos, quatro vezes por semana. Antes e depois de seis semanas de treinamento, os indivíduos realizaram o ensaio de resistência e um estudo da função endotelial por ultrassom de alta resolução da artéria braquial. Resultados: Depois da hiperemia, a porcentagem do diâmetro arterial foi significativamente maior para o grupo de alta intensidade. (Al antes $=2,52 \pm 2,85 \mathrm{~mm}$ e depois $=31,81 \pm 12,21 \mathrm{~mm}$; $B$ antes $=3,23 \pm 3,52 \mathrm{~mm}$ e depois $=20,61 \pm 7,76 \mathrm{~mm}$; controles antes $=3,56 \pm 2,33 \mathrm{~mm}$ e depois $=2,43 \pm$ $2,14 \mathrm{~mm} ; p<0,05)$. Conclusões: O treinamento aeróbico de alta intensidade melhorou o endotélio de modo dependente da resposta vasodilatadora, constatada por meio de ultrassom, em pacientes com síndrome metabólica e diabetes tipo 2.

Descritores: ultrassom; diabetes mellitus tipo 2; exercício.

\section{RESUMEN}

Introducción: Diabetes mellitus es la enfermedad metabólica más común en todo el mundo. La disfunción endotelial característica de estos pacientes es uno de los principales factores de riesgo para la aterosclerosis. El diagnóstico precoz de la disfunción endotelial es esencial para el tratamiento, sobre todo de forma no invasiva como la dilatación mediada por flujo. El ejercicio es capaz de Generar adaptaciones beneficiosas mejorando la función endotelial. Objetivo: Identificar los efectos del ejercicio de alta intensidad, utilizando la técnica clínica del ultrasonido en la evaluación de la función endotelial en pacientes con síndrome metabólico o diabetes mellitus tipo 2. Métodos: Se estudiaron 31 pacientes con diabetes mellitus tipo 2 o síndrome metabólico, con una edad media ( $\pm D E)$ de $58 \pm 6$ años, divididos aleatoriamente en tres grupos. El entrenamiento se llevó a cabo durante 50 minutos, cuatro veces por semana. Antes y después de seis semanas de entrenamiento, los sujetos realizaron la prueba de resistencia y un estudio de la función endotelial mediante ultrasonido de alta resolución de la arteria braquial. Resultados: Después de hiperemia, el porcentaje de diámetro arterial fue significativamente mayor en el grupo de alta intensidad (Al antes $=2,52 \pm 2,85 \mathrm{~mm}$ y después $=31,81 \pm 12,21 \mathrm{~mm}$; 
Bl antes $=3,23 \pm 3,52 \mathrm{~mm}$ y después $=20,61 \pm 7,76 \mathrm{~mm}$; controles antes $=3,56 \pm 2,33 \mathrm{~mm}$ y después $=2,43 \pm$ $2,14 \mathrm{~mm} ; p<0,05)$. Conclusiones: El entrenamiento aeróbico de alta intensidad, mejoró el endotelio de manera dependiente de la respuesta vasodilatadora, registrado por ultrasonido, en sujetos con síndrome metabólico y diabetes tipo 2.

Descriptores: ultrasonido; diabetes mellitus tipo 2; ejercicio

\section{INTRODUCTION}

Diabetes mellitus (DM) is the most common metabolic disease worldwide occurring in approximately 381.8 million adults in 2013 and with projection to rise to 591.9 million in $2035^{1}$. High glucose concentrations are responsible for increases in the formation of reactive oxygen species (ROS), with decreased nitric oxide and increased expression of inflammatory cytokines that contribute to endothelial dysfunction².

The endothelium is responsible for maintaining homoeostasis between vasodilation and vasoconstriction stimuli by synthesizing a variety of molecules that act as agonists or antagonists, thus, in endothelial dysfunction the endothelium becomes vulnerable and leaky to inflammatory cells and lipids, forming atherosclerotic plaques ${ }^{3}$. In these patients the formation of atherosclerotic plaques are accelerated, but the mechanisms responsible for this accelerated development remain unclear, nevertheless, redox imbalance due to excess production of reactive oxygen species-mediated Nox 1 seems to be one of the pathways ${ }^{4}$. However, atherosclerosis is the major cause of morbidity and mortality observed in $\mathrm{DM}^{5}$. The endothelial function in periphery conduit arteries affects directly in coronary circulation, therefore impaired endotheliumdependent vasodilation can predicts cardiovascular events ${ }^{6}$. Endothelium dependent dilation can be quantified by Flow-Mediated Dilation (FMD) and used as an index for endothelium function. The non-invasive nature of this technique permits repeated measurements over time?.

Exercise can be used as a non-pharmacological instrument to promote central (cardiovascular) and peripheral (skeletal muscle) adaptations that are linked to improved health outcomes ${ }^{8,9}$. Several studies have shown that high intensity training improves endothelial function due a vasorelaxation mediated an increased e-NO and IGF-1 receptor expression, including in patients with type 2 diabetes and transplanted hearts ${ }^{10,8,11}$, suggesting an anti-atherosclerotic effect of exercise.

The purpose of the present study was to identify the effect of an aerobic physical training program, use of Ultrasound clinical technique, in the endothelial function of patients with metabolic syndrome or diabetes mellitus type two.

\section{METHODS}

\section{Subjects}

Subjects with metabolic syndrome or diabetes mellitus type two, of both sexes, with age between 40 and 65 years, without coronary arterial disease were studied. This study was led in the Section of Prevention and Cardiovascular Rehabilitation Unicardio, in the Hospital Santa Catarina, in the city of Blumenau, in the State of Santa Catarina, Brazil. The following exclusion criteria were used: subjects in whom, for reasons related to their clinical screening, it was not possible to suspend medicines with known effect on endothelial function, as inhibitors of the enzyme converting angiotensin, calcium channels blockers, nitrates, beta-blockers, anti-oxidizers, hormonal replacement, insulin; subjects with altered strength test (positive); cigarette smoking history in the last 12 months; participation in a physical exercise program in the last 12 months; chronic obstructive lung disease; high pressure levels (systolic blood pressure above $180 \mathrm{mmHg}$ and diastolic blood pressure above $110 \mathrm{mmHg}$ ); diagnosed osteoporosis and diabetic neuropathy.

All the participants were informed regarding the objectives of the study and about the possible risks and discomforts involved with their participation in the experiments, signing term of informed consent. The study protocol was approved by the Commission of Ethics and Researches of Hospital Santa Catarina. This project is framed in the category II of the research regulation in men, in Brazil ${ }^{12}$, where in agreement with article 13 of the referred resolution.

\section{Protocol}

All study patients underwent an initial clinical examination with a cardiologist. Before and after 6 weeks of intervention, the patients performed the strength test, physical exam and, evaluation of endothelial function. The participants of this study were submitted to program of physical exercise in the Section of Prevention and Cardiovascular Rehabilitation Unicardio of Hospital Santa Catarina, in Blumenau, State of Santa Catarina. The participants were guided to keep the original alimentary habits and behaviors. After the strength test limited by fatigue, the participants were guided with base in their individual prescription of exercises, and randomized for a low (50 to 60\% HRmaximum) or high 75 to $85 \%$ HRmaximum) intensity. During the study period, the patients maintained the same doses of medicines.

\section{Program of aerobic training}

In both programs, the patients trained four times a week, $50 \mathrm{mi}-$ nutes for session. Each session of physical exercise was divided in: five minutes of warm up, with stretching exercises and circling of members and body; 40 minutes of aerobic exercises (walk and/or run), being the first 10 minutes progressive until reaching the training target, and after, 30 minutes in the training target; and five minutes of cold down at the end, with stretching, flexibility and relaxation exercises. The part of aerobic exercise of each session was continuous. The six weeks consisted of two weeks of progressive adaptation phase and four weeks training in the target predetermined by the maximum heart frequency. The exercise sessions were supervised by one of the investigators and the determined intensity of exercise was monitored and registered for each patient by a watch of heart frequency (Polar, I Model M62, Helsinki, Finland). The alarms of the watches were programmed for the inferior and superior limits of the correspondent intensity, determined for each patient.

\section{Assessment of functional capacity}

The exercise test was performed at Unicardio/HSC Clinics of Hospital Santa Catarina, downtown Blumenau, by a cardiologist that didn't know the group to the which the patients were randomized in. An ergometric treadmill with computerized system (I Raise PC Micromed, I Model Millenium EM200 Plus, Brasília, Distrito Federal, Brazil). Bruce's ${ }^{13}$ protocol was chosen. Initially a standing rest electrocardiogram was made and the blood pressure was measured; the electrocardiogram was observed continuously; blood pressure was measured to each 
period; the test was interrupted by physical exertion of the evaluated subject, and in a gradual way; the room temperature was maintained at $24^{\circ} \mathrm{C}$ by air conditioning.

\section{Assessment of the endothelial function}

All the patients were submitted to a non-invasive evaluation of the endothelial function, performed at Clínica Uniangio, in the city of Blumenau, Brazil. Two investigators performed all the tests, without knowledge of the groups to which the patients were randomized. They were in fast from eight to 12 hours; the temperature adaptation was in $24^{\circ} \mathrm{C}$; vasoactive medicines were suspended for approximately 4 half-lives; the patients didn't train in the day of the exam; they were oriented to not ingest substances that affected the vasodilatation mediated by the flow (FMD) for at least 24 hours before the exam, as caffeine, fatty foods, vitamin C, alcohol; no make use of tobacco; it was observed that the women were not in menstrual period; the individual was positioned lying, with the arms in prone in a comfortable position, to obtain image of the brachial artery, above the sewage antecubital, in the longitudinal plan, as seen in one of the evaluated subjects, shown at Figure 1.

A supersonic sound waves was used (Acuson, Model 128XP System, Montain View, California, USA), with vascular software for bidimensional images (2D), color Doppler and ghastly, with a monitor of internal electrocardiogram (ECG) and, a vascular transducer of high frequency (Acuson, Model L7 7,5-10 MHz, Montain View, California, USA). After the positioned subject, a segment with interfaces summons previous and subsequent between the lumen and the arterial wall and selected for images in tones of ash 2D. The images in tones of ash 2D, so much the way $M$ and the way A (location of walls) they can be used to measure the diameter continually. The registrations of the arterial diameters were recorded in ribbon super-VHS for subsequent analysis. The whole reading happened after frozen the plan in the pick of the wave R in ECG in three measured sequences, repeating in more two waves $R$ (therefore they were nine measures, making the average at the end), as shown in one of the subject of the research, seen at Figure 1. Vasodilatation Mediated by the Flow (FMD) Dependent of Endothelium: to create a flow incentive in the brachial artery, an sphygmomanometer cuff was placed below the sewage antecubital; an image in rest of the line base was acquired after 10 minutes of rest, obtained of a sample of volume of the middle of the artery; after that, the occlusion of the artery was created by the insufflations of the cuff for the supra-systolic pressure; typically, the fist was insufflated at least $50 \mathrm{mmHg}$ above the pressure basal systolic measure in the opposite arm, for occlusion of the arterial influx for extension of standardized time; that caused ischemic and consequent dilation down of the resistance vases through mecha-

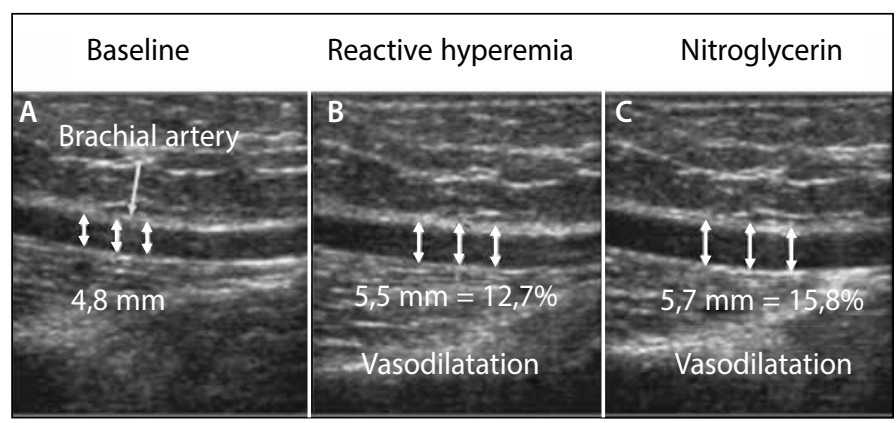

Figure 1. Image of the brachial artery seen by the Supersonic sound waves, longitudinally, in a patient of the study: a) Image of baseline after 10 minutes of rest; $b$ ) Image 60 seconds after the deflation of a ischemic cuff of 5 minutes; c) Image after 4 minutes of the administration of sublingual nitrate. nisms solemnity-flow through the brachial artery (reactive hyperemia for five minutes), to accommodate the extensive resistance vases; the resulting increase in the stress cut caused dilation in the brachial artery; the longitudinal image of the artery was registered continually before of 30 seconds for two minutes after the deflation of the fist (peak \pm 60 seconds); a pulsed sign Doppler of the middle of the brachial artery was obtained after the immediate release of the cuff and not later than 15 seconds after the deflation of the cuff to evaluate the arterial diameter in $\mathrm{mm}^{14}$. Vasodilatation Mediated by the Flow (FMD) Independent of Endothelium: There were necessary 10 minutes of rest after the reactive hyperemia (FMD), before other image could be acquired to reflect the conditions of re-established baseline; after having re-established the baseline noticed in the image, it was made administration of 0,4mg-Pumpspray of NitrolingualR (Wirkstoff: Nitroglycerin, Gesmbh, Vienna, Austria); the vasodilatation peak happened three to four minutes after having administered the substance (it was measured again after 4 minutes of the administration of the nitrate); the images were continually registered; the nitrate was not administered in individuals with bradicardia or serious hypertension; the nitrate, which is a exogenous donor of nitric oxide (NO), it has been used to determine the maximum vasodilatory answer that one can obtain, and to serve as a measure of independent vasodilatation of the endothelium reflecting the vascular function of the smooth musclé.

\section{Statistical analysis}

The size of the sample was calculated with base in previous studies ${ }^{15-17}$. The data were initially evaluated for the test of Kolmogorov-Smirnova to establish the normality. The variables with normal distribution are presented by mean \pm DP and the variables that didn't have normal distribution they are presented by mean土EP. For the data with normal distribution, analysis of variance of couple entrance for repeated data was used to compare the effects of the interventions and multiple comparisons were performed by the test of Tukey. Variables without normal distribution were evaluated by the test Kruskal-Wallis, with multiple comparisons performed by the test $U$ of Mann-Whitney. The significance level $=5 \%$ ( 0,05$)$.

\section{RESULTS}

\section{Characteristics of the subjects}

Thirty eight subjects were studied. Seven subjects were excluded of the study (six with suspicion of DAC with test of altered strength; one with hip surgery not recovered). Thirty one subjects were randomly designated to your groups, as demonstrated in the Table 1.

Table 1. Characteristics of the subjects in the study, in their respective groups.

\begin{tabular}{|c|c|c|c|}
\hline & $\begin{array}{c}\text { High Intensity } \\
\text { Group }\end{array}$ & $\begin{array}{c}\text { Low Intensity } \\
\text { Group }\end{array}$ & $\begin{array}{l}\text { Control } \\
\text { Group }\end{array}$ \\
\hline $\mathrm{N}$ & 10 & 10 & 11 \\
\hline Age (years) & $50,7 \pm 9,2$ & $52,2 \pm 7,5$ & $49,5 \pm 6,8$ \\
\hline Men / Women & $03 / 07$ & $05 / 05$ & $03 / 08$ \\
\hline $\begin{array}{c}\text { Diabetes Type } 2 \\
(\text { Glucose }>126 \mathrm{mg} / \mathrm{dL})^{*}\end{array}$ & 02 & 02 & 04 \\
\hline $\begin{array}{c}\text { Metabolic Syndrome } \\
(\geq 3 \text { risk factors })^{* *}\end{array}$ & 08 & 08 & 07 \\
\hline $\begin{array}{c}\text { Pré-Hypertension } \\
(120-139 / 80-89 \mathrm{mg} / \mathrm{dL})^{* * *}\end{array}$ & 02 & 05 & 02 \\
\hline Hypertension $(>140 / 90 \mathrm{~mm} / \mathrm{Hg})^{* * *}$ & 06 & 04 & 09 \\
\hline Total CHOL $\uparrow(>200 \mathrm{mg} / \mathrm{dL})^{* *}$ & 05 & 05 & 07 \\
\hline Overweight (IMC 25-29,9 Kg/m²) $)^{* * * *}$ & 03 & 07 & 04 \\
\hline Obesity $\left(\mathrm{IMC}>30 \mathrm{Kg} / \mathrm{m}^{2}\right)^{* * * *}$ & 05 & 01 & 05 \\
\hline $\mathrm{CC} \uparrow(\mathrm{H}>102 / \mathrm{M}>88)^{* *}$ & 08 & 06 & 10 \\
\hline
\end{tabular}

* Report of the Expert Committee on the Diagnosis and Classification of Diabetes Mellitus, 2003. ** ATP III, 2001. *** Joint National Committee on Prevention, Detection, Evaluation, and Treatment of Blood Pressure, 2003. **** WHO, 2004. 


\section{Program of training}

All the patients participated of the 24 training sessions. During the training sessions, the heart frequency was confronted at 20 minutes of training, as seen in Figure 2, where the group of high intensity maintained a frequency heart average of $79 \pm 3 \% \mathrm{bpm}$, while the group of low intensity maintained a medium frequency of $55 \pm 2 \%$ bpm.

\section{Study of the endothelial function}

After six weeks of exercise training, a significant improvement was observed in the dependent dilation of the endothelium, being the larger increase in the group of training of high intensity compared with the one of low intensity. Inversely, in the control group the change in the diameter of the vase was not significantly different from those of the initial study. Table 2 displays the diameters of the brachial artery before and after the exercise program of the patients of the research.

Figure 3 shows the percentage difference of expansion, compared before and after the study, after reactive hyperemia. There is a significant difference in vasodilation in high and low intensity groups, although higher in the high-intensity group compared with the control group.

\section{DISCUSSION}

The main finding of the present study was to show that patients with metabolic syndrome or Type 2 Diabetes have a significantly accentuated response regarding the dilation of the brachial artery in the endothelium dependent function (reactive hyperemia), but not to nitroglycerin, after a six weeks aerobic physical exercise program, that improvement being maximized with high-intensity exercise. The physical exercise training also improved glycemic profile, LDL cholesterol profile and duration of the strength test.

Our findings have shown that high-intensity exercise can improve vasorelaxation in DM patients through the endothelium-dependent pathway. Recently, studies comparing the effects of continuous and high-intensity interval exercise on endothelium-dependent vasodilation in DM patients prove increased aerobic capacity ${ }^{18}$, flow-mediated

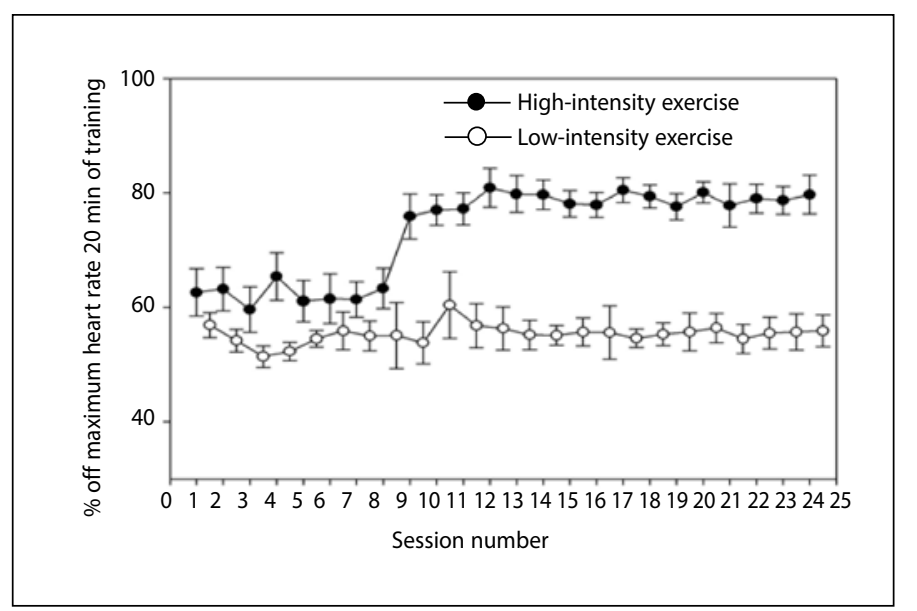

Figure 2. Graphic representation of the percentile of the heart frequency, of the training groups, per Session.

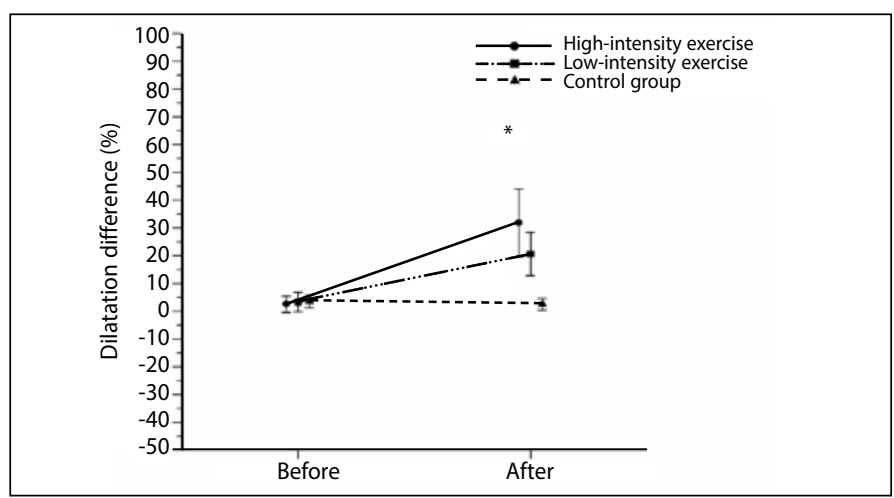

Figure 3. Graphic representation of the Percentage the Dilation of the Brachial Artery before and after, Endothelium-Dependent, per Group, posts Reactive Hyperemia ( $p<0,05$ by the test of Tukey).

dilation ${ }^{19,18}$, and cutaneous reactive hyperemia ${ }^{18}$ in both groups, but the magnitude of improvements was greater in patients undergoing interval training. These results are accompanied by a decrease in oxidative stress and serum von Willebrand factor ${ }^{18}$ as well as increases in antioxidant defenses ${ }^{19,18}$ and endothelial nitric oxide ${ }^{20,18}$. However, endothelium-dependent vasodilation was directly proportional to the antioxidant defense and intensity of training ${ }^{19}$, suggesting that the characteristic oxidative stress in diabetic patients influences directly on endothelial dysfunction. In hypertensive rats the high-intensity exercise ameliorated endothelial function by IGF-1 and insulin induced vasorelaxation compared with the sedentary group. However, when an antioxidant pretreatment vasorelaxant was used responses became similar in all groups ${ }^{10}$.

Still evaluating the effect of low-volume high-intensity interval exercise, Little et al. ${ }^{21}$ have been shown to decreased hyperglycemia and improvement muscle mitochondrial capacity in patients with type 2 diabetes subjected to two weeks of training. The glycemic control is important aspect for the treatment of DM due hyperglycemia is a risk factor for the development of several physiological disorders that contribute to endothelial dysfunction and consequently atherosclerosis formation?

Interestingly, Goto et al..22, evaluating the intensity of training of physical exercise, obtained an inverse result to those of our study. They demonstrated that 12 weeks of low-intensity physical exercise (65\% of the maximum heart rate), but not high-intensity physical exercise ( $90 \%$ of the maximum heart rate), increased the endothelium-dependent vasodilation in 26 healthy men.

In healthy populations, mean FMD ranges from 0.20 to $20 \%$, although in our study, the average vasodilation after intervention was higher than that found in the literature ${ }^{23}$. For subjects with T2DM mediated vasodilation flow ranged from 0.75 to $12 \%$, confirming our findings, showing that the subjects in our research were initially with endothelial dysfunction, being restored after six weeks of exercise ${ }^{23}$. Our study is in agreement with the literature ${ }^{24}$, mainly standardizing occlusion location (upper arm) and duration of occlusion (five minutes), annulling possible differences due to technical aspects.

The consistence of previously published data ${ }^{17,25}$, shown above, indicate

Table 2. Mean and Standard Deviation Values of Endothelial Dysfunction.

\begin{tabular}{|c|c|c|c|c|c|c|c|c|c|c|}
\hline \multirow{2}{*}{ Variables } & \multicolumn{2}{|c|}{ High Intensity Group } & \multicolumn{2}{|c|}{ Low Intensity Group } & \multicolumn{2}{|c|}{ Control Group } & \multicolumn{3}{|c|}{ P Value } & \multirow{2}{*}{$\begin{array}{c}\text { Post-Hoc } \\
\text { Tukey }\end{array}$} \\
\hline & Before & After & Before & After & Before & After & Timing & Interaction & Group & \\
\hline Base Diameter $(\mathrm{mm})$ & $4,18 \pm 0,74$ & $4,31 \pm 0,95$ & $4,11 \pm 0,48$ & $4,25 \pm 0,53$ & $4,16 \pm 0,41$ & $4,12 \pm 0,22$ & 0,238 & 0,420 & 0,918 & $N / S^{*}$ \\
\hline Reactive Hyperemia (mm) & $4,28 \pm 0,73$ & $5,62 \pm 0,95$ & $4,24 \pm 0,48$ & $5,10 \pm 0,55$ & $4,31 \pm 0,37$ & $4,22 \pm 0,23$ & $<0,001$ & $<0,001$ & 0,037 & $<0,031 \mathrm{GAl}^{*}$ \\
\hline $\begin{array}{c}\text { Induced Dilatation } \\
\text { NTG (mm) }\end{array}$ & $5,22 \pm 1,02$ & $5,67 \pm 0,95$ & $5,17 \pm 0,60$ & $5,41 \pm 0,58$ & $4,96 \pm 0,36$ & $4,62 \pm 0,36$ & 0,103 & $<0,001$ & 0,073 & $N / S^{*}$ \\
\hline
\end{tabular}

* Used statistic ANOVA with Post-Hoc Tukey. 
that exercise training improves endothelial function in heterogeneous groups, including groups where patients presented this dysfunction due to injury, corroborating with the results of our study and contrasting with studies of exercise training in subjects with normal endothelial function.

One cannot forget to highlight that the improvement in vascular function is evident in every vasculature, even if exercise is only practiced in the inferior limbs, excluding the remaining of the body. So, it is evident that the effect of exercise training becomes widespread, and not restricted to the vascular bed of the musculature, as demonstrated by Köller et al. ${ }^{25}$, Maiorana et al. ${ }^{27}$ and, Green et al. ${ }^{28}$. One additional explanation for the improvement in endothelium dependent vasodilation could be the changes for the training of aerobic physical exercise in fasting glucose and glycated hemoglobin ${ }^{27,29-31}$, in the lipid concentrations in the blood, specifically the LDL cholesterol ${ }^{32-34}$.

\section{LIMITATIONS}

This study was of short duration. Although that Hornig et al. ${ }^{35}$ highlight that the prejudiced endothelial function already presents improvement after four weeks of intervention with exercise. Endothelial function is a precocious marker of cardiovascular disease. But, although this study didn't evaluate long term issues, it is justified in the literature that intense exercise reduces cardiovascular risk ${ }^{36-39}$. Ostergard et al. ${ }^{40}$ is that the vascular function can improve at the beginning of the study and to begin a worsening after some weeks of intervention with exercise of high intensity, fact not noticed in our study, although with a time of intervention of six weeks.

But, in general, the evaluation is supersonic sound waves of the brachial artery Has Been surrendering important information about the vascular function in the health and in the disease, when taken due care in the technical application. Although, more long term studies and with clinically important issues shouldn't be performed.

\section{CONCLUSIONS}

When compared to the aerobic training of low intensity and controls, the aerobic training of high intensity improved vasodilatatory response endothelium-dependent in patients with metabolic syndrome or DM2, measured by the technique flow-mediated vasodilatation (FMD) of the brachial artery. These findings suggest that the physical training of high intensity could be considered as a preventive alternative on those patients.

All authors have declared there is not any potential conflict of interests concerning this article.

AUTORES' CONTRIBUTIONS: CAS (0000-0002-9267-0735)* and FSLV-F (0000-0003-3140-0085)* were the main contributors to the writing of the manuscript. EB (00000002-3908-1667)* and CAS performed the clinical ultrasound procedures. MS (0000-0002-9986-5332)*, RCR-S (0000-0002-6487-0334)*, CP (0000-0003-1829-1515)*, FAOM $(0000-0001-7109-9448)^{*}$ and SILM $(0000-0003-3611-634 X)^{*}$ conducted the literature review, revised the manuscript, and contributed to the intellectual concept of the study. *ORCID (Open Researcher and Contributor ID).

\section{REFERENCES}

1. Guariguata L, Whiting DR, Hambleton I, Beagley J, Linnenkamp U, Shaw JE.Global estimates of diabetes prevalence for 2013 and projections for 2035. Diabetes Res Clin Pr. 2014;103(2):137-149.

2. Shenouda SM, Widlansky ME, Chen $K, X$ U G, Holbrook M, Tabit CE, et al. Altered mitochondrial dynamics contributes to endothelial dysfunction in diabetes mellitus. Circulation. 2011;124(4), 444-453.

3. Jansson PA. Endothelial dysfunction in insulin resistance and type 2 diabetes. J Intern Med. 2007;262(2), 173-183.

4. Gray SP, Di Marco E, Okabe J, Szyndralewiez C, Heitz F, Montezano AC, et al. NADPH oxidase 1 plays a key role in diabetes mellitus-accelerated atherosclerosis. Circulation, 2013;127(18), 1888-1902.

5. Siracuse JJ, Chaikof EL. The Pathogenesis of Diabetic Atherosclerosis. In Shrikhande GV, McKinsey JF. Diabetes and Peripheral Vascular Disease: Diagnosis and Management. Springer Science \& Business Media; 2012. p. 13-26.

6. Anderson TJ, Uehata A, Gerhard MD, Meredith IT, Knab S, Delagrange D, et al. Close relation of endothelial function in the human coronary and peripheral circulations. J Am Coll Cardiol. 1995;26(5), 1235-1241.

7. Goldfine AB, Buck JS, Desouza C, Fonseca V, Chen YDI, Shoelson SE, et al. Targeting inflammation using salsalate in patients with type 2 diabetes: effects on flow-mediated dilation (TINSAL-FMD). Diabetes care. 2013;36(12), 4132-4139.

8. Hermann TS, Dall CH, Christensen SB, Goetze JP, Prescott E, Gustafsson F. Effect of High Intensity Exercise on Peak Oxygen Uptake and Endothelial Function in Long- Term Heart Transplant Recipients. Am J Transplant. 2011);11(3), 536-541.

9. Gibala MJ, Little JP, MacDonald MJ, Hawley JA. Physiological adaptations to low-volume, high-intensity interval training in health and disease. J Physiol. 2012;590(5), 1077-1084.

10. Yang AL, Lo CW, Lee JT, Su CT. Enhancement of vasorelaxation in hypertension following high-intensity exercise. Chin J Physiol. 2011;54(2), 87-95.

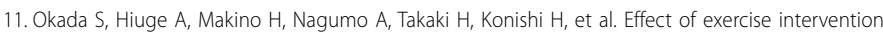
on endothelial function and incidence of cardiovascular disease in patients with type 2 diabetes. J Atheroscl and Thromb. 2010;17(8): 828-833.

12. Celermajer DS, Sorensen KE, Gooch VM, Sullivan ID, Lloyd JK., Deanfield JE, Spiegelhalter, DJ. Non-invasive detection of endothelial dysfunction in children and adults at risk of atherosclerosis. Lancet 1992:340:1111-5.

13. Bruce RA. Multi-stage treadmill test of submaximal and maximal exercise. Exercise testing and training of apparently healthy individuals: a handbook for physicians. 1972;32-34.

14. Conselho Nacional de Saúde. Resolução 01/88. Normas de Pesquisa em Saúde. In: Diário Oficial da União. 1996;14/06:10713/10.

15. Corretti MC, Aanderson TJ, Benjamim EJ, Celermajer D, Charbonneau F, Creager MA, et al. Guedelines for the ultrasound assessment of endothelial-dependent flow-mediated vasodilatation of the brachial artery. J Am Coll Cardiol. 2002;39(2):257-65.

16. Allen JD, Geaghan JP, Greenway F, Welsch MA. Time course of improved flow-mediated dilation after short-term exercise training. Med Sci Sports Exerc 2003;35(5):847-853.

17. Maiorana A, O'Driscoll G, Dembo L, Goodman C, Taylor R, Green D. Exercise training, vascular function, and functional capacity in middle-aged subjects. Med Sci Sports Exerc. 2001;33(12):2022-2028.

18. Mitranun W, Deerochanawong C, Tanaka H, Suksom D. Continuous vs interval training on glycemic control and macro- and microvascular reactivity in type 2 diabetic patients. Scand J Med Sci Spor. 2014:24(2):69-76.

19. Tyldum GA, Schjerve IE, Tjønna AE, Kirkeby-Garstad I, Stølen TO, Richardson RS, Wisløff U. Endothelial dysfunction induced by post-prandial lipemia: complete protection afforded by high-intensity aerobic interval exercise. J Am Coll Cardiol. 2009;53(2), 200-206.

20. Kobayashi T, Kamata K. Short-term insulin treatment and aortic expressions of IGF-1 receptor and VEGF mRNA in diabetic rats. Am. J. Physiol. Heart Circ. 1995;26(5), 1235-1241.

21. Little JP, Gillen JB, Percival ME, Safdar A, Tarnopolsky MA, Punthakee Z, Gibala MJ. Low-volume high- -intensity interval training reduces hyperglycemia and increases muscle mitochondrial capacity in patients with type 2 diabetes. J Appl Physiol. 2011;111(6), 1554-1560.

22. Goto C, Higashi Y, Kimura M, Noma K, Hara K, Nakagama K, Kawamura M, et al. Effect of different intensities of exercise on endothelial-dependent vasodilatation in humans: role of endothelium-dependent nitric oxide and oxidative stress. Circulation 2003; 108:530-535.

23. Lavrencic A, Salobir BG, Keber I. Physical training improves flow-mediated dilation in patients with the poly-metabolic syndrome. Arterioscler Thromb Vasc Biol. 2000;20:551-555.

24. Shechter M, Sharir M, Labador MJP, Forrester J, Mierz CNB. Improvement in endothelium-dependent brachial artery flow-mediated vasodilatation with low-density lipoprotein cholesterol levels $<100$ mg/dL. Am J Cardiol. 2000;86:1256-1259.

25. Middlebrooke AR, Armstrong N, Welsman JR, Shore AC, Clarkt P, Macleod KM. Does aerobic fitness influence microvascular function in healthy adults at risk of developing type 2 diabetes. Diabet Med. 2005;22:483-489.

26. Köller A, Huang A, Sun D, Kalley G. Exercise training augments flow-dependent dilatation in rat skeletal muscle arterioles. Circ Res. 1995;76:544-50.

27. Maiorana A, O'Driscoll G, Dembo L, Cheetham C, Goodman C, Taylor R,et al. Effect of aerobic and resistance exercise training on vascular function in heart failure. Am J Physiol. 2000;279:1999-2005.

28. Green DJ, Maiorana A, O'Driscoll G, Taylor R. Effect of exercise training on endothelium-derived nitric oxide function in humans. J Physiol. 2004;561(1):1-25.

29. Ivy JL. Role for exercise training in the prevention and treatment of insulin resistance and non-insulin-dependent diabetes mellitus. Sport Med. 1997:24:321-36.

30. Mayer-Davis EJ, D'AgostinoJr R, Karter AJ, Haffner SM, Rewers MJ, Saad M,et al. Intensity and amount of physical activity in relation in insulin sensitivity - The Insulin Resistance Atherosclerosis Study. JAMA. 1998;279:669-74

31. Dunstan DW, Puddey IB, Beilin L, Burke V, Morton AR, Stanton KG. Effects of a short-term circuit weight training program on glycaemic control in NIDDM. Diabetes Res Clin Pract. 1998;40:53-61.

32. Ishii T, Yamakita T, Sato T, Tanaka S, Fujii S. Resistance training improves insulin sensitivity in NIDDM subjects without altering maximal oxygen uptake. Diabetes Care. 1998;98:894-8.

33. Ohara Y, Peterson TE, Sayegh HS, Subramanian RR, Wilcox JN, Harrison DG. Dietary correction of hypercholesterolemia in the rabbit normalizes endothelial superoxide anion production. Circulation. 1995;92:898-903.

34. Sheu WHH, Chen YT, Lee WJ. Improvement in endothelial dysfunction with LDL cholesterol level $<80$ $\mathrm{mg} / \mathrm{dL}$ in type 2 diabetic patients. Diabetes Care. 2001;24(8):1489-1501.

35. Hornig B, Maier $\mathrm{V}$, Drexler H. Physical training improves endothelial function in patients with chronic heart failure. Circulation. 1996;93(2):210-214

36. Benetti M, Matos ABM, Herdy AH, Carvalho T, Carvalho JA, Ribeiro JP. Improvement in endothelial function with high-intensity exercise training in patients with coronary artery disease. Eur Heart Journal. 2006:27 (Abstract suppl):444.

37. Tanasescu M, Leitzmann MF, Rimm EB, Hu FB. Physical activity in relation to cardiovascular disease and total mortality among men with type 2 diabetes. Circulation. 2003;107:2435-2439.

38. Yu S, Yarnell JWG, Sweetnam PM, Murray L. What level of physical activity protects against premature cardiovascular death? The Caerphilly Study. Heart 2003:89:502-506.

39. Hambrecht R, Niebauer J, Marburger C, Grunze M, Kälberer B, Hauer K, et al. Various intensities of leisure time physical activity in patients with coronary artery disease: Effects on cardiorespiratory fitness and progression of coronary atherosclerotic lesions. J Am Coll Cardiol. 1993;22:468-7.

40. Ostergard T, Nyholm B, Hansen TK, Rasmussen LM, Ingerslev J, Sorensen KE, et al. Endothelial function and biochemical vascular markers in first-degree relatives of type 2 diabetic patients: the effect of exercise training. Metabolism 2006:55:1508-1515. 